\title{
Evaluating the 3-m tree crown spacing guideline for the preven- tion of crowning wildfires in lodgepole pine forests, Alberta
}

\author{
By Martin E. Alexander1,\% and Miguel G. Cruz²
}

\begin{abstract}
A 3-m between crown spacing is a commonly cited criterion found in the wildland-urban interface fire literature for minimizing the likelihood of a fully-developed crown fire from occurring in a conifer forest on level terrain. The validity of this general recommendation is examined here in light of our current state-of-knowledge regarding crown fire propagation in relation to canopy bulk density. Given the characteristics of the overstory structure for 20 lodgepole pine (Pinus contorta Dougl. ex Loud. var. latifolia Engelm.) stands located in Alberta, as sourced from the literature, the canopy fuel properties following a virtual thinning to a $3-\mathrm{m}$ crown spacing and then to a targeted canopy bulk density of $0.05 \mathrm{~kg} / \mathrm{m}^{3}$ were computed. On the basis of these computations, crown fire potential was then analyzed and interpreted. The conclusion reached is that, in the majority of cases, a less widely spaced stand would be adequate for preventing crown fire development in lodgepole pine forests.
\end{abstract}

Keywords: active crown fire, canopy base height, canopy bulk density, canopy fuel load, crown fire initiation and propagation, fire behaviour, fireline intensity, fuel management, onset of crowning, passive crown fire, rate of fire spread, stand structure, thinning

\section{RÉSUMÉ}

On retrouve souvent dans la littérature scientifique sur les incendies forestiers le critère d'espacement de $3 \mathrm{~m}$ entre les cimes pour minimiser les chances de développer un feu de cime dans les forêts périurbaines sur terrain plat. Cet article se penche sur la validité de cette recommandation générale dans l'état actuel des connaissances sur la propagation des feux de cimes en fonction de la densité apparente du couvert forestier. À partir des caractéristiques structurales de couvert de 20 peuplements de pin lodgepole (Pinus contorta Dougl. ex Loud. var. latifolia Engelm.) de l'Alberta documentés dans les ouvrages scientifiques, nous avons calculé les propriétés combustibles du couvert résultant d'une éclaircie virtuelle à un espacement de $3 \mathrm{~m}$ entre les cimes puis à une densité apparente du couvert de $0,05 \mathrm{~kg} / \mathrm{m}^{3}$. À partir de ces calculs, nous avons analysé et estimé le risque de feux de cime pour ces forêts. Nous en concluons que, dans la plupart des cas, un espacement plus étroit suffirait à prévenir le développement de feux de cime dans les forêts de pin lodgepole.

Mots-clés : feu de cime actif, hauteur de la base de cime, densité apparente du couvert, charge de combustible du couvert, naissance et propagation du feu dans le couvert, comportement de l'incendie, intensité de la ligne antifeu, gestion du combustible, déclenchement d'un feu de cime, feu de cime passif, taux de propagation de l'incendie, structure de peuplement, éclaircie

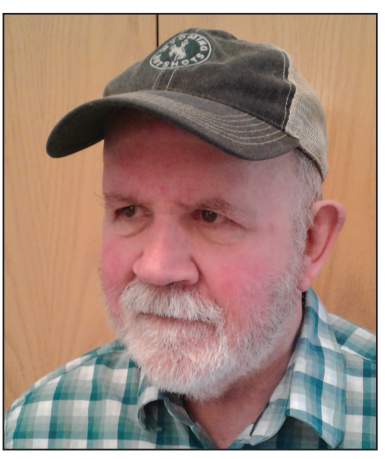

Martin E. Alexander

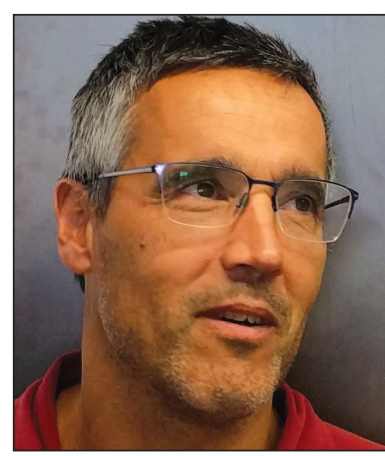

Miguel G. Cruz

\section{Introduction}

Crowning wildfires, with their associated "wall of flame", represent very exciting and visually striking natural phenomenon (Fig. 1a-c). They are, however, very difficult if not impossible to bring under control until burning conditions ameliorate and thus pose a serious threat to life, property, and natural resources in coniferous forested areas (Alexander and Cruz 2016). The best strategy for reducing the potential of such wildland conflagrations is to create fuel situations whereby firefighting techniques can be effective, thereby limiting the size and intensity potential of free-burning wildfires (Countryman 1974).

Thinning of coniferous stands has been suggested as a fuel treatment measure in order to prevent or mitigate against the

\footnotetext{
${ }^{1}$ R.P.F., Wild Rose Fire Behaviour, 180 - 50434 Range Road 232, Leduc County, Alberta, Canada T4X 0L1. ${ }^{\star}$ Corresponding author. E-mail: mea2@telus.net

${ }^{2}$ CSIRO, GPO Box 1700, Canberra, Australian Capital Territory, Australia 2601
} 

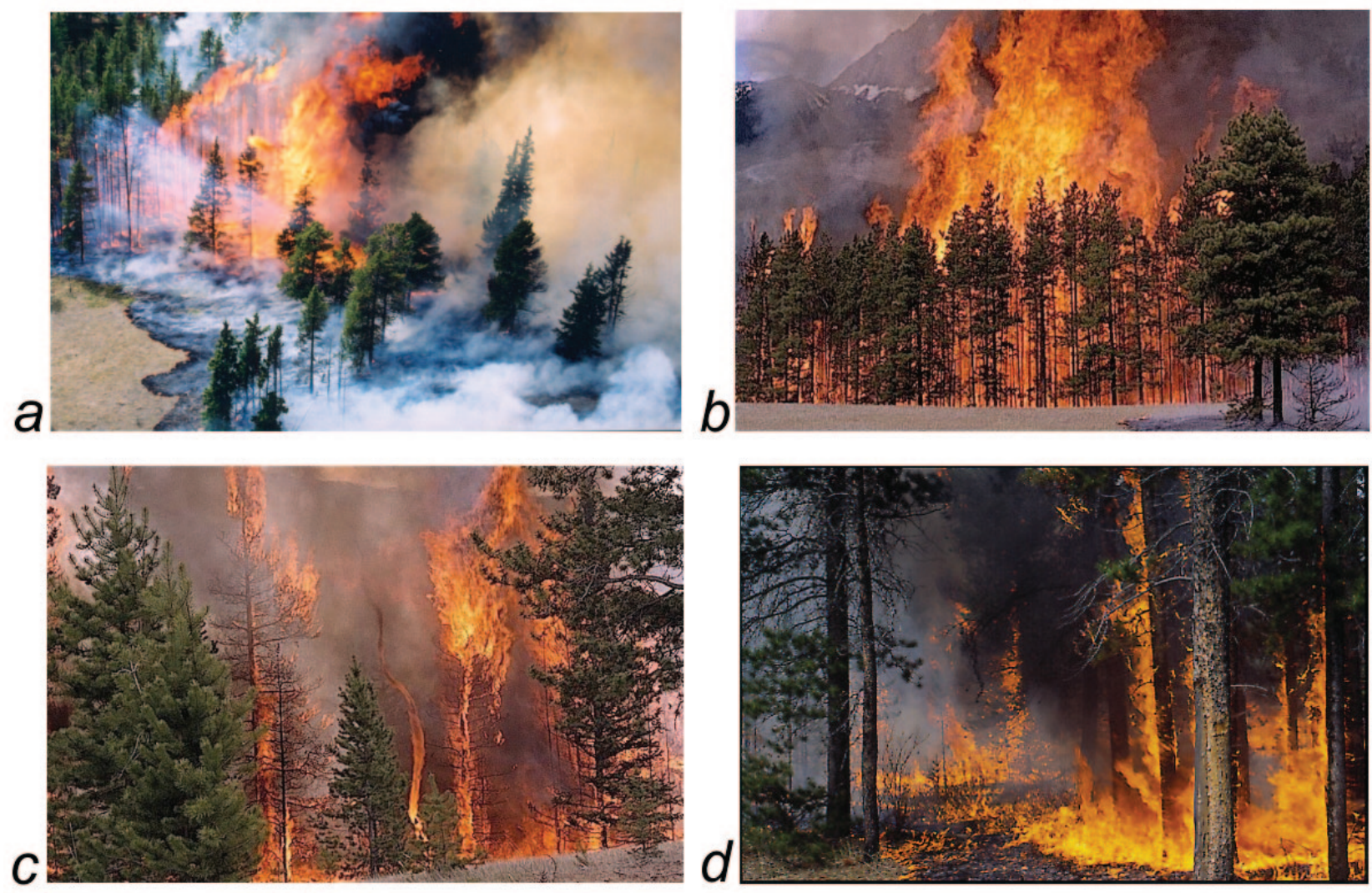

Fig. 1 Variations in fire behaviour within a lodgepole pine fuel complex in the Athabasca River valley of Jasper National Park, west-central Alberta, Canada, on May 23, 2001: (a-b) active crown fire, (c) passive crown fire, and (d) surface fire involving ladder fuel engagement. Photo (a) by Colin Pinkoski and photos (b-d) by Brian Amiro, Canadian Forest Service. For further details, see Amiro et al. (2004).

possibility of crown fire development (Graham et al. 1999; Agee and Skinner 2005) and thereby increase the chances of controlling wildfires by conventional means. In publications issued by the Colorado State Forest Service, Dennis (1983, 2005) recommended a minimum 3-m (or $10-\mathrm{ft}$ ) spacing between conifer crowns; the most recent publication on home protection from wildfire in the wildland-urban interface (WUI) contains the same guideline (Colorado State Forest Service 2012). The recommendation made by Dennis (1983) gradually came to appear in the WUI fire literature (e.g., Schmidt and Wakimoto 1988; Fischer and Simmerman 1990). It is now widely quoted as a guide for rural forest homeowners in other regions of the western U.S. (e.g., Hunter et al. 2007; BonFire Steering Committee 2016; Jones et al. 2016). However, to the best of our knowledge, this general guideline has no theoretical and/or empirical basis.

Coincidentally, a 3-m between crown spacing guideline was also recommended by Partners in Protection, an Albertabased organization addressing WUI fire issues; a spacing of 6-m between crowns may be required in some situations (e.g., steep slopes). This guideline, derived from a consultant's report (Arbor Wildland Management Services 1999), is based in part on a National Fire Protection Association (1991) standard as detailed in the FireSmart: Protecting Your Community from Wildfire manual, initially published in 1999 and again in a second edition four years later (Partners in Protection 2003). This publication has since been advocated by FireSmart Canada (https://www.firesmartcanada.ca/). To date, the governments of British Columbia, Manitoba, Saskatchewan, Northwest Territories, Yukon Territory, Newfoundland \& Labrador and Alberta (e.g., Alberta Government 2013) as well as other organizations (e.g., Institute of Catastrophic Loss Reduction 2019), have in turn developed their own specific booklets on the basis of this more comprehensive, technical publication.

The purpose of the present paper is to provide an appraisal of the 3-m between crown spacing guideline in light of our current understanding and knowledge of crown fire behaviour phenomena in relation to coniferous stand structure. ${ }^{1}$ Lodgepole pine (Pinus contorta Dougl. ex Loud. var. latifolia Engelm.) in Alberta was selected as a candidate forest cover type because of its uniform fuel conditions and because of its connection to the WUI fire problem in the province (Pengelly 1993; Dam 1999; Westhaver 2006).

${ }^{3}$ For further information, consult the Crown Fire Behavior Characteristics and Prediction in Conifer Forests: A State of Knowledge Synthesis project website at: https://www.fs.fed.us/wwetac/brief/ CrownFireSynthesis.php [Accessed 4 November 2019]. 
We begin with an overview of the general requirements for the start and spread of crown fires in conifer forests and then present the calculations involved in determining the stand structure and canopy fuel characteristics in lodgepole pine stands following a virtual thinning in relation to the 3-m between crown spacing guideline and the criteria for fullydeveloped crowning. The implications of this evaluation in terms of the 3-m crown spacing guideline are discussed and finally we offer some thoughts on future directions with respect to fuel treatments. A summary list of the variables referred to throughout the paper is provided at the end of the text.

\section{Primer on crown fire initiation and propagation Onset of crowning}

For a crown fire to start, a surface fire (Fig. 1d) of sufficient intensity is first needed (Lawson 1973). The most commonly used method for evaluating such a threshold is based on Byram's (1959) concept of fireline intensity $\left(I_{B}, \mathrm{~kW} / \mathrm{m}\right)$, defined as the rate of heat released from a linear segment of the fire perimeter. $I_{B}$ is calculated as follows:

$$
I_{B}=H \times w \times(R \div 60)
$$

where, $H$ is the low heat of combustion reduced for fuel moisture content $(\mathrm{kJ} / \mathrm{kg}), w$ is the quantity of fuel consumed in the flaming front $\left(\mathrm{kg} / \mathrm{m}^{2}\right)$, and $R$ is the rate of fire spread ( $\mathrm{m} / \mathrm{min})$. A nominal value for $H$ is 18 $000 \mathrm{~kJ} / \mathrm{kg}$ (Forestry Canada Fire Danger Group 1992). For further information on $I_{B}$ and its calculation, refer to Alexander (1982).

$I_{B}$ is also a useful index or guide to the limits on the type of fire suppression forces capable of controlling certain wildfires (Alexander 2000). For example, at $500 \mathrm{~kW} / \mathrm{m}$, ground crews can effectively suppress fires with hand tools but as intensities approach 2000 $\mathrm{kW} / \mathrm{m}$ require support from helicopters and air tankers to contain a wildfire. At around $4000 \mathrm{~kW} / \mathrm{m}$, aerial resources start to become ineffective and once $I_{B}$ levels exceed 10000 $\mathrm{kW} / \mathrm{m}$, wildfires are generally not possible to control until the severity of weather and/or fuel conditions lessen.

When a fire begins to crown in a conifer forest (Fig. 1c), additional fuel in the form of needles and small twigs is consumed (Van Wagner 1977). At the same time, a fire's spread rate typically doubles at a very minimum (McArthur 1965). Given these combined results, $I_{B}$ levels can easily quadruple in value (e.g., from 3000 to $12000 \mathrm{~kW} / \mathrm{m}$ ) once a fire begins to crown. This is why limiting crown fire potential, especially in and/or near the WUI, takes on such critical importance.
While several models have been developed for judging the potential for the onset of crowning, Van Wagner's (1977) is by far the simplest in terms of the fewest number of inputs. He was able to construct a method to assess the requirements for crown fire initiation on the basis of two canopy fuel properties, namely canopy base height $(\mathrm{CBH}, \mathrm{m})$ and foliar moisture content (FMC,\% oven-dry weight basis) in relation to the $I_{B}$ of a surface fire, using the following equation (after Van Wagner 1977):

$$
I_{o}=(0.010 \times C B H \times(460+26 \times F M C))^{1.5}
$$

where, $I_{o}(\mathrm{~kW} / \mathrm{m})$ is the critical surface fire $I_{B}$ needed for initial crown combustion.

The initiation of crowning (Fig. 1c) is expected to occur when a surface fire's $I_{B}$ is greater than or equal to $I_{o}$, otherwise if $I_{B}$ is less than $I_{o}$, a surface fire is expected to prevail. Van Wagner (1977) assumed that ladder or bridge fuels (e.g., bark flakes on tree boles, tree lichens, tall shrubs, understory trees, dead bole branches, and suspended needles) existed in sufficient quantity to help intensify the surface fire and extend the flames vertically (Fig. 1d).

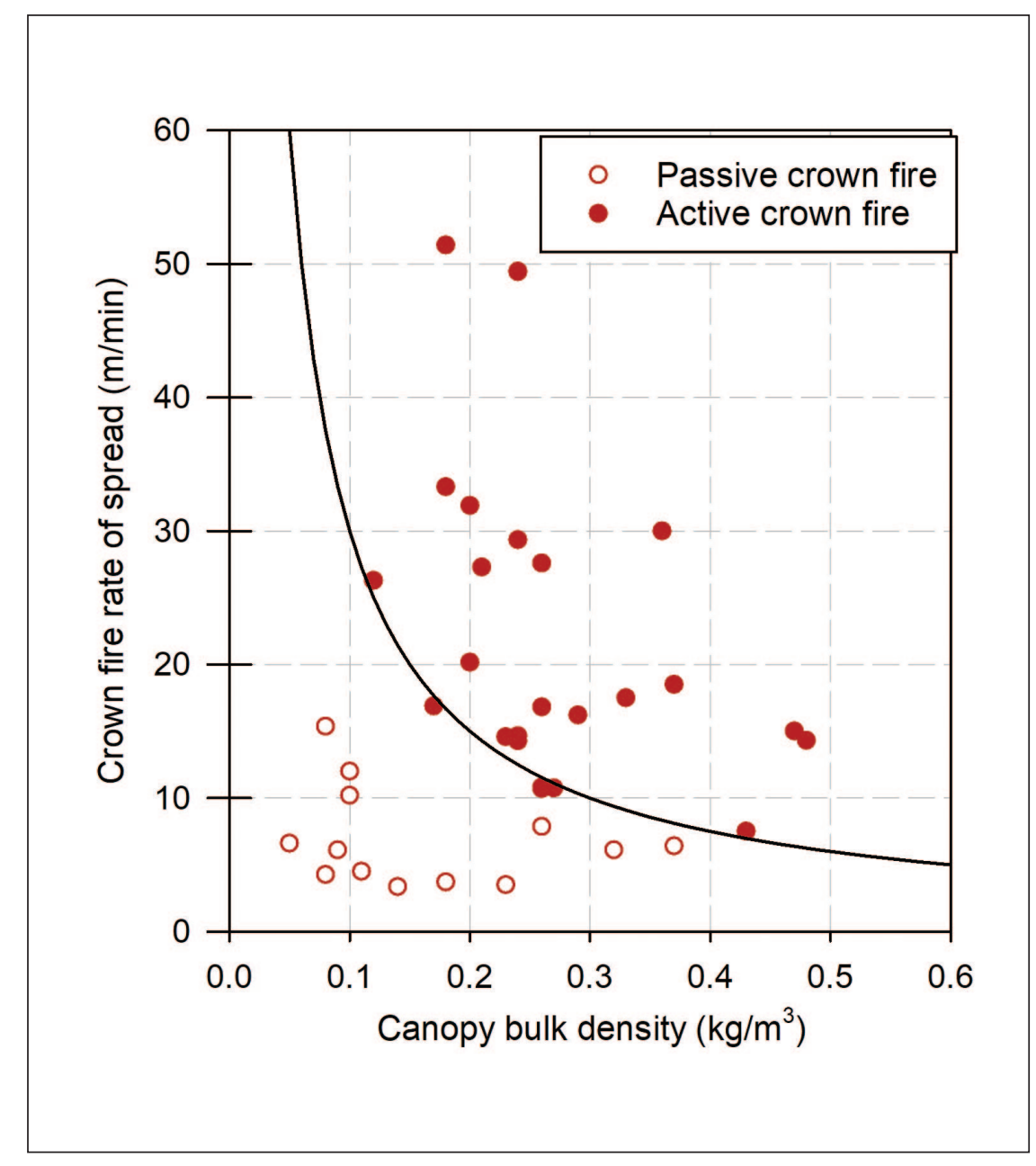

Fig. 2 Critical minimum spread rate for active crowning in a conifer forest stand as a function of canopy bulk density according to Van Wagner's (1977) crown fire propagation model, represented by Eq. (3), in relation to plotted experimental crown fire data (after Cruz and Alexander 2010). 
Active crown fire spread

Van Wagner (1977) also proposed criteria for determining the requirement for a fully-developed crown fire to occur in relation to coniferous forest stand structure once the requirements for the onset of crowning had been met according to the following equation:

$$
R_{o}=3.0 \div C B D
$$

where $R_{o}(\mathrm{~m} / \mathrm{min})$ is the critical minimum spread rate for active crown fire and $C B D\left(\mathrm{~kg} / \mathrm{m}^{3}\right)$ is the canopy bulk density (Fig. 2). Subsequent research has shown this to be a robust relationship (Cruz and Alexander 2010).

For consistency with Van Wagner's (1977) theory represented by Eq. (3), $C B D$ is computed as follows:

$$
C B D=C F L \div C D
$$

where CFL is the canopy fuel load $\left(\mathrm{kg} / \mathrm{m}^{2}\right)$ comprised solely of needle foliage and $C D$ is the live crown depth (m).

Fully-developed or active crowning (Fig. 1a-b) is expected to occur when the surface fire $I_{B}$ is great than or equal to $I_{0}$ and the $R$ after the onset of crowning is greater than or equal to $R_{o}$ (Van Wagner 1977). On the other hand, passive or less than fully-developed crowning (Fig. 1c) is expected to occur when the surface fire $I_{B}$ is greater than or equal to $I_{o}$ but $R$ remains less than $R_{o}$, in which case some partial canopy fuel consumption is possible (Stocks 1989) but complete combus- tion of the entire fuel complex by the advancing flame front is not expected to occur.

It is worth noting that passive crown fires (Fig. 1c) can occur under two broad situations. In one situation, the $\mathrm{CBH}$ and $C B D$ are considered optimum, but fuel moisture and wind conditions are not quite severe enough to induce active crowning. In another distinct scenario, the $C B D$ is below the threshold necessary for fully-developed crowning (e.g., tallor open-forest stand types), so that even under severe burning conditions (i.e., critically dry fuels and strong surface winds), active crown fire spread (Fig. 1a-b) is not possible, although vigorous, high-intensity fire behaviour can still take place.

Agee (1996) was the first to suggest, on the basis of information gleaned from seven stands on a single wildfire, that a $C B D$ of about $0.1 \mathrm{~kg} / \mathrm{m}^{3}$ should be regarded as a critical threshold value for active crowning in conifer forests. The Canadian Forest Service has been carrying out experimental crown fires in standing timber types since 1962 (Van Wagner 1964; Stocks et al. 2004). They have yet to achieve an active crown fire with a $C B D$ of less than $0.12 \mathrm{~kg} / \mathrm{m}^{3}$ or experience a passive crown fire on an experimental basis with a $C B D$ of less than $0.04 \mathrm{~kg} / \mathrm{m}^{3}$ (Fig. 2). According to Eq. (3), the critical minimum active crown spread rates for $C B D$ values of 0.05 and $0.1 \mathrm{~kg} / \mathrm{m}^{3}$ are 60 and $30 \mathrm{~m} / \mathrm{min}$, respectively. Data obtained from wildfire documentation do indicate that crown fire rates of spread of 30 to $60 \mathrm{~m} / \mathrm{min}$ and even higher are indeed possible in conifer forests (Alexander and Cruz 2006).

Table 1. Tree, stand and canopy fuel characteristics for 20 untreated lodgepole pine stands located in Alberta as sourced from the literature and their associated crowning criteria according to Van Wagner (1977); abbreviations and symbols are listed at

\begin{tabular}{|c|c|c|c|c|c|c|c|c|c|c|}
\hline $\begin{array}{c}\text { Stand } \\
\text { Identifier }\end{array}$ & $\begin{array}{l}S H \\
(\mathbf{m})\end{array}$ & $\begin{array}{l}D B H \\
(\mathrm{~cm})\end{array}$ & $\begin{array}{l}C D \\
\text { (m) }\end{array}$ & $\begin{array}{c}S D \\
\text { (stems/ha) }\end{array}$ & $\begin{array}{c}B A \\
\left(\mathbf{m}^{2} / \mathbf{h a}\right)\end{array}$ & $\begin{array}{c}C B H \\
(\mathbf{m})\end{array}$ & $\begin{array}{c}C F L \\
\left(\mathbf{k g} / \mathbf{m}^{2}\right)\end{array}$ & $\begin{array}{c}C B D \\
\left(\mathrm{~kg} / \mathrm{m}^{3}\right)\end{array}$ & $\begin{array}{c}I_{o} \\
(\mathrm{~kW} / \mathrm{m})\end{array}$ & $\begin{array}{c}\boldsymbol{R}_{\boldsymbol{o}} \\
(\mathbf{m} / \mathbf{m i n})\end{array}$ \\
\hline \multicolumn{11}{|c|}{ Bessie and Johnson (1995) } \\
\hline 2 & 14.3 & 15.4 & 7.1 & 2530 & 47.4 & 7.2 & 1.12 & 0.16 & 3270 & 19.0 \\
\hline 3 & 14.8 & 16.9 & 4.7 & 2170 & 48.7 & 10.1 & 1.16 & 0.25 & 5433 & 12.2 \\
\hline 4 & 6.5 & 8.4 & 2.1 & 7230 & 40.3 & 4.4 & 1.40 & 0.67 & 1562 & 4.5 \\
\hline 5 & 9.3 & 13.6 & 4.6 & 3770 & 55.1 & 4.7 & 2.42 & 0.53 & 1725 & 5.7 \\
\hline 6 & 8.7 & 13.4 & 3.2 & 3330 & 47.1 & 5.5 & 2.05 & 0.64 & 2183 & 4.7 \\
\hline 9 & 11.3 & 14.3 & 5.3 & 2100 & 33.5 & 6.0 & 0.94 & 0.18 & 2488 & 16.9 \\
\hline 10 & 9.9 & 13.3 & 3.9 & 3130 & 43.6 & 6.0 & 1.08 & 0.28 & 2488 & 10.8 \\
\hline 11 & 12.4 & 23.4 & 7.5 & 1730 & 74.3 & 4.9 & 2.85 & 0.38 & 1836 & 7.9 \\
\hline 16 & 18.3 & 18.9 & 4.6 & 1970 & 55.5 & 13.7 & 1.06 & 0.23 & 8583 & 13.0 \\
\hline 20 & 6.8 & 13.7 & 3.7 & 1700 & 25.1 & 3.1 & 0.83 & 0.22 & 924 & 13.4 \\
\hline 21 & 13.5 & 16.9 & 7.4 & 1470 & 33.1 & 6.1 & 0.73 & 0.10 & 2550 & 30.4 \\
\hline 23 & 10.9 & 13.8 & 3.7 & 3900 & 58.6 & 7.2 & 2.20 & 0.59 & 3270 & 5.0 \\
\hline 25 & 7.4 & 9.2 & 3.7 & 7000 & 46.5 & 3.7 & 1.90 & 0.51 & 1205 & 5.8 \\
\hline 27 & 8.4 & 16.7 & 5.6 & 1570 & 34.3 & 2.8 & 0.73 & 0.13 & 793 & 23.0 \\
\hline 29 & 11.9 & 16.5 & 7.6 & 1870 & 40.0 & 4.3 & 1.14 & 0.15 & 1509 & 20.0 \\
\hline 33 & 11.5 & 17.2 & 4.9 & 1930 & 44.6 & 6.6 & 0.94 & 0.19 & 2870 & 15.6 \\
\hline 35 & 3.2 & 6.9 & 3.1 & 2270 & 8.4 & 0.1 & 0.26 & 0.08 & 5 & 35.8 \\
\hline 43 & 6.3 & 16.3 & 5.8 & 1870 & 38.9 & 0.5 & 0.38 & 0.07 & 60 & 45.8 \\
\hline \multicolumn{11}{|c|}{ Hirsch and Pengelly (2000) } \\
\hline Untreated & 14.2 & 14.5 & 6.5 & 2825 & 46.7 & 7.7 & 1.67 & 0.26 & 3617 & 11.5 \\
\hline \multicolumn{11}{|c|}{ Cruz et al. $(2014)^{\star}$} \\
\hline Untreated & 14.2 & 13.3 & 5.9 & 4050 & 56.5 & 9.2 & 2.07 & 0.35 & 4723 & 8.6 \\
\hline
\end{tabular}
the end of the text

${ }^{\star}$ For further information, see Dam (1999) 
However, the $C B D$ values associated with these data can only be very broadly judged. On the weight of the available empirical evidence, the critical threshold for crown fire propagation can be considered to be a $C B D$ of around $0.05 \mathrm{~kg} / \mathrm{m}^{3}$.

The use of the "passive" term here should not lead one to believe that this type of fire behaviour is some kind of benign form of crown fire. Passive crown fires (Fig. 1c) are, like active crown fires (Fig. 1a-b), not only dangerous from a personal safety standpoint, they are also capable of supporting $I_{B}$ levels above $10000 \mathrm{~kW} / \mathrm{m}$ (Van Wagner 1977).

\section{Canopy fuel properties and crowning criteria prior to stand thinning}

The pre-treatment characteristics of 20 even-aged lodgepole pine stands are presented in Table 1. This data was sourced from the peer-reviewed literature. Other potential datasets (e.g., Rudnicki et al. 2004; Fish et al. 2006) did not include the necessary measurements such as canopy base height and canopy fuel load or the individual plot information had not been archived (e.g., White 1985).

Nineteen of the 20 stands were located in southwestern Alberta, 18 in the Kananaskis Valley (Bessie and Johnson 1995), and one stand in Banff National Park (Hirsch and Pengelly 2000) plus a stand near the town of Whitecourt in central Alberta (Cruz et al. 2014). Of the 47 subalpine stands sampled by Bessie and Johnson (1995), only those exhibiting greater than $90 \%$ lodgepole pine composition were selected for the dataset analyzed in this paper.
The information in Table 1 represents a relatively wide range of stand conditions from a fuel-fire perspective as evident by the computed crown fire initiation and propagation criteria of Van Wagner (1977). According to Eq. (2), given the $C B H$ values of 0.1 to $13.7 \mathrm{~m}$ and applying a $F M C$ of $100 \%$ representing conditions in early August (Fuglem and Murphy 1980; Fingland 1987), $I_{o}$ levels would range from 5 to $8583 \mathrm{~kW} / \mathrm{m}$ (Table 2). Based on the $C B D$ values of 0.07 to $0.67 \mathrm{~kg} / \mathrm{m}^{3}, R_{o}$ levels would, according to Eq. (3), range from 4.5 to $45.8 \mathrm{~m} / \mathrm{min}$. Note that the pre-thinning $C B D$ values for all 20 of the stands presented in Table 1 are greater than 0.05 $\mathrm{kg} / \mathrm{m}^{3}$. White (1985) found on the basis of 130 plots that $C B D$ values in the three forest types dominated by lodgepole pine in Banff National Park, averaged from 0.14 to $0.24 \mathrm{~kg} / \mathrm{m}^{3}$ with maximums ranging from 0.35 to $0.79 \mathrm{~kg} / \mathrm{m}^{3}$.

\section{Changes in canopy fuel properties following stand thinning}

Several calculations are needed to compute canopy fuel properties following thinning to the 3-m between crown spacing standard for a given stand. The steps involved in the calculation process consists of seven steps. Of the 20 stands, stand 2 of Bessie and Johnson (1995) was selected to illustrate the calculation process.

Step 1. The following standard forest mensuration formula (i.e., Davis 1966: 43) is used to calculate the average spacing between tree stems $(S, \mathrm{~m})$ from the stand density $(S D$, stems/ha):

Table 2. Tree, stand and canopy fuel characteristics for 20 lodgepole pine stands located in Alberta prior to and following thinning to a 3-m between crown spacing; abbreviations and symbols are listed at the end of the text

\begin{tabular}{|c|c|c|c|c|c|c|c|}
\hline $\begin{array}{l}\text { Stand } \\
\text { Identifier }\end{array}$ & $\underset{(\mathbf{m})}{S}$ & $\begin{array}{l}C W \\
(\mathrm{~m})\end{array}$ & $\begin{array}{c}I^{I C O^{*}} \\
(\mathbf{m})\end{array}$ & $\begin{array}{l}S_{t} \\
(\mathbf{m})\end{array}$ & $\begin{array}{c}S D_{t} \\
\text { (stems/ha) }\end{array}$ & $\underset{\left(\mathrm{kg} / \mathrm{m}^{2}\right)}{C F L_{t}}$ & $\begin{array}{c}C B D_{t} \\
\left(\mathrm{~kg} / \mathrm{m}^{3}\right)\end{array}$ \\
\hline \multicolumn{8}{|c|}{ Bessie and Johnson (1995) } \\
\hline 2 & 2.0 & 2.3 & 0.3 & 5.3 & 359 & 0.16 & 0.022 \\
\hline 3 & 2.1 & 2.5 & 0.3 & 5.5 & 335 & 0.18 & 0.038 \\
\hline 4 & 1.2 & 1.2 & 0.0 & 4.2 & 578 & 0.11 & 0.053 \\
\hline 5 & 1.6 & 1.9 & 0.2 & 4.9 & 421 & 0.27 & 0.059 \\
\hline 6 & 1.7 & 1.8 & 0.1 & 4.8 & 429 & 0.26 & 0.083 \\
\hline 9 & 2.2 & 2.0 & -0.2 & 5.0 & 396 & 0.18 & 0.033 \\
\hline 10 & 1.8 & 1.9 & 0.1 & 4.9 & 423 & 0.15 & 0.037 \\
\hline 11 & 2.4 & 3.1 & 0.7 & 6.1 & 266 & 0.44 & 0.058 \\
\hline 16 & 2.3 & 2.8 & 0.6 & 5.8 & 293 & 0.16 & 0.034 \\
\hline 20 & 2.4 & 1.8 & -0.6 & 4.8 & 436 & 0.21 & 0.058 \\
\hline 21 & 2.6 & 2.4 & -0.2 & 5.4 & 340 & 0.17 & 0.023 \\
\hline 23 & 1.6 & 2.0 & 0.4 & 5.0 & 407 & 0.23 & 0.062 \\
\hline 25 & 1.2 & 1.3 & 0.1 & 4.3 & 545 & 0.15 & 0.040 \\
\hline 27 & 2.5 & 2.2 & -0.3 & 5.2 & 370 & 0.17 & 0.031 \\
\hline 29 & 2.3 & 2.3 & 0.0 & 5.3 & 355 & 0.22 & 0.028 \\
\hline 33 & 2.3 & 2.4 & 0.1 & 5.4 & 347 & 0.17 & 0.034 \\
\hline 35 & 2.1 & 0.9 & -1.2 & 3.9 & 674 & 0.08 & 0.025 \\
\hline 43 & 2.3 & 2.1 & -0.2 & 5.1 & 389 & 0.08 & 0.014 \\
\hline \multicolumn{8}{|c|}{ Hirsch and Pengelly (2000) } \\
\hline Untreated & 1.9 & 2.2 & 0.3 & 5.2 & 374 & 0.22 & 0.034 \\
\hline \multicolumn{8}{|l|}{ Cruz et al. (2014) } \\
\hline Untreated & 1.6 & 2.0 & 0.5 & 5.0 & 396 & 0.20 & 0.034 \\
\hline
\end{tabular}

${ }^{*} \mathrm{~A}$ negative $I C O$ value indicates that on average there is separation distance between crowns 


$$
S=\sqrt{ } 10000 \div S D
$$

For a $S D$ of 2530 stems/ha, this equates to an $S$ of $2.0 \mathrm{~m}$ (Table 2 ), representing the pith to pith distance between tree stems.

Step 2. The average crown width $(C W, \mathrm{~m})$ or crown diameter of the trees is estimated in the stand. In the absence of an existing model to predict $C W$ for Alberta lodgepole pine, the following equation, based on a study by Bonnor (1964) in lodgepole pine at the Kananaskis Forest Experiment Station in southwestern Alberta ${ }^{4}$, is used to estimate $C W$ from diameter at breast height $(D B H, \mathrm{~cm})$ and stand height $(S H, \mathrm{~m})$ :

$$
C W=-0.07303+0.11691 \times D B H+0.03805 \times S H
$$

given a $D B H$ of $15.4 \mathrm{~cm}$ and a $S H$ of $14.3 \mathrm{~m}$, the estimated $C W$ is $2.3 \mathrm{~m}$ (Table 2) according to Eq. (6).

Step 3. Assuming a uniform spatial distribution of trees throughout the stand and a circular crown shape centered on the tree pith, we then calculate the presumed inter-crown overlap $(I C O, \mathrm{~m})$ as follows:

$$
I C O=C W-S
$$

For a $C W$ of $2.3 \mathrm{~m}$ and an $S$ of $2.0 \mathrm{~m}$, there would therefore be an ICO for each stem of $0.3 \mathrm{~m}$ (Table 2).

Step 4. To meet the 3-m distance between tree crowns criteria, the average distance between tree boles in the stand would have to be increased by a thinning operation. To determine the desired tree spacing following thinning $\left(S_{t}, \mathrm{~m}\right)$, the $C W$ estimate would be added to the recommended distance between tree crowns of $3.0 \mathrm{~m}$ :

$$
S_{t}=3.0+C W
$$

Considering the estimated $C W$ of $2.3 \mathrm{~m}$ for the trees in the stand plus the $3.0 \mathrm{~m}$ between crowns, $S_{t}$ amounts to approximately $5.3 \mathrm{~m}$ (Table 2 ).

Step 5. To compute the equivalent stand density for this level of thinning $\left(S D_{t}\right.$, stems/ha), Eq. (6) is used:

$$
S D_{t}=10000 \div S_{t}^{2}
$$

For a $S_{t}$ of $5.3 \mathrm{~m}$, this would equate to an $S D_{t}$ of 359 stems/ha (Table 2).

Step 6. To estimate the canopy fuel load following thinning $\left(C F L_{t}, \mathrm{~kg} / \mathrm{m}^{2}\right)$ is accomplished using the following relation:

$$
C F L_{t}=\left(C F L \times S D_{t}\right) \div S D
$$

Given a $C F L$ of $1.12 \mathrm{~kg} / \mathrm{m}^{2}$, a $S D_{t}$ of 359 stems/ha and a $S D$ of 2530 stems/ha, the estimated $C F L_{t}$ would therefore equal $0.16 \mathrm{~kg} / \mathrm{m}^{2}$ (Table 2).

Step 7. The canopy bulk density following thinning $\left(C B D_{t}, \mathrm{~kg} / \mathrm{m}^{3}\right)$ would, by Eq. (4), be $0.022 \mathrm{~kg} / \mathrm{m}^{3}$ (Table 2$)$ given a $C D$ of $7.1 \mathrm{~m}$.

The preceding computations were based on the assumption that there are no significant changes in tree dimensions and canopy fuel properties following thinning. However, the mean $\mathrm{DBH}$ and $\mathrm{SH}$ do in fact increase after thinning (Cruz and Alexander 2012) and the increase in growing space will result in each tree eventually being able to laterally expand its canopy and sustain a larger quantity of foliage.

\footnotetext{
4The dataset is based on eight 0.04-ha sample plots with the $S D$ ranging from 2125 to 12502 stems/ha. The plot averages of $C W$, $D B H$ and $S H$ ranged from 1.7 to $3.0 \mathrm{~m}, 10.2$ to $20.3 \mathrm{~cm}$ and 10.1 to $18.6 \mathrm{~m}$, respectively. Eq. (6) exhibited a coefficient of determination $\left(\mathrm{R}^{2}\right)$ of 0.77 .
}

The $C B D_{t}$ values in Table 2 represent exceedingly low levels of crowning potential. Considering stand 2 of Bessie and Johnson (1995), given a $C D$ of $7.1 \mathrm{~m}$ and a $C B D_{t}$ of 0.05 $\mathrm{kg} / \mathrm{m}^{3}$ and working back through Eq. (4), the CFL equals 0.36 $\mathrm{kg} / \mathrm{m}^{2}$ (Table 3). Given the calculated $C F L_{t}$ working back through Eq. (10), that $S D_{t}$ equals 802 stems/ha (Table 3) which, in turn, represents an $S_{t}$ of $3.5 \mathrm{~m}$ (Table 3) according to Eq. (5). Given the $2.3 \mathrm{~m} \mathrm{CW}$ value derived earlier, the average between crown spacing $(C S, \mathrm{~m})$ to mitigate against the potential for crown fire propagation is $1.2 \mathrm{~m}$ (Table 3 ).

For the 20 stands overall, the CS necessary to reduce the $C B D$ to a targeted value of $0.05 \mathrm{~kg} / \mathrm{m}^{3}$, averaged $2.4( \pm 0.9) \mathrm{m}$ and varied between 0.6 and $4.4 \mathrm{~m}$ (Table 3 and Fig. 3). Fourteen of the 20 stands $(70 \%)$ had a CS less than $2.5 \mathrm{~m}$, averaging $1.9( \pm 0.5) \mathrm{m}$. While there is no strong discernible pattern between the $C S$ and either $S H$ or $D B H$ (Fig. 3a-b), as the $S D$ decreases so does the CS (Fig. 3c).

\section{Discussion and conclusion}

Based on the results presented in the preceding section, a general recommendation for an across-the-board 3-m between crown spacing by thinning for the prevention of crowning wildfires in lodgepole pine forests does not appear warranted. In our analysis, such a prescription simply leads to excessive thinning in most circumstances. As shown here, there will be situations where a certain stand structure warrants a $\geq 3-\mathrm{m}$ crown spacing.

The 3-m between crowning spacing guideline is also sim-

\begin{tabular}{|c|c|c|c|c|}
\hline $\begin{array}{l}\text { Stand } \\
\text { Identifier }\end{array}$ & $\begin{array}{c}C F L \\
\left(\mathrm{~kg} / \mathrm{m}^{2}\right)\end{array}$ & $\begin{array}{c}S D_{t} \\
\text { (stems/ha) }\end{array}$ & $\begin{array}{c}S_{t} \\
(\mathbf{m})\end{array}$ & $\begin{array}{l}C S \\
(\mathrm{~m})\end{array}$ \\
\hline \multicolumn{5}{|c|}{ Bessie and Johnson (1995) } \\
\hline 2 & 0.36 & 802 & 3.5 & 1.2 \\
\hline 3 & 0.24 & 440 & 4.8 & 2.3 \\
\hline 4 & 0.11 & 542 & 4.3 & 3.1 \\
\hline 5 & 0.23 & 358 & 5.3 & 3.4 \\
\hline 6 & 0.16 & 260 & 6.2 & 4.4 \\
\hline 9 & 0.27 & 592 & 4.1 & 2.1 \\
\hline 10 & 0.20 & 565 & 4.2 & 2.3 \\
\hline 11 & 0.38 & 228 & 6.6 & 3.5 \\
\hline 16 & 0.23 & 427 & 4.8 & 2.0 \\
\hline 20 & 0.19 & 379 & 5.1 & 3.3 \\
\hline 21 & 0.37 & 745 & 3.7 & 1.2 \\
\hline 23 & 0.19 & 328 & 5.5 & 3.6 \\
\hline 25 & 0.19 & 682 & 3.8 & 2.5 \\
\hline 27 & 0.28 & 602 & 4.1 & 1.9 \\
\hline 29 & 0.38 & 623 & 4.0 & 1.7 \\
\hline 33 & 0.25 & 503 & 4.5 & 2.1 \\
\hline 35 & 0.16 & 1353 & 2.7 & 1.9 \\
\hline 43 & 0.29 & 1427 & 2.6 & 0.6 \\
\hline \multicolumn{5}{|c|}{ Hirsch and Pengelly (2000) } \\
\hline Untreated & 0.33 & 543 & 4.3 & 2.1 \\
\hline \multicolumn{5}{|c|}{ Cruz et al. (2014) } \\
\hline Untreated & 0.30 & 579 & 4.2 & 2.1 \\
\hline
\end{tabular}
plistic, in the sense that it does not take into account $\mathrm{CBH}$, an

Table 3. Tree, stand and canopy fuel characteristics for 20 lodgepole pine stands located in Alberta assuming a targeted canopy bulk density of $0.05 \mathrm{~kg} / \mathrm{m}^{3}$ following thinning; abbreviations and symbols are listed at the end of the text 

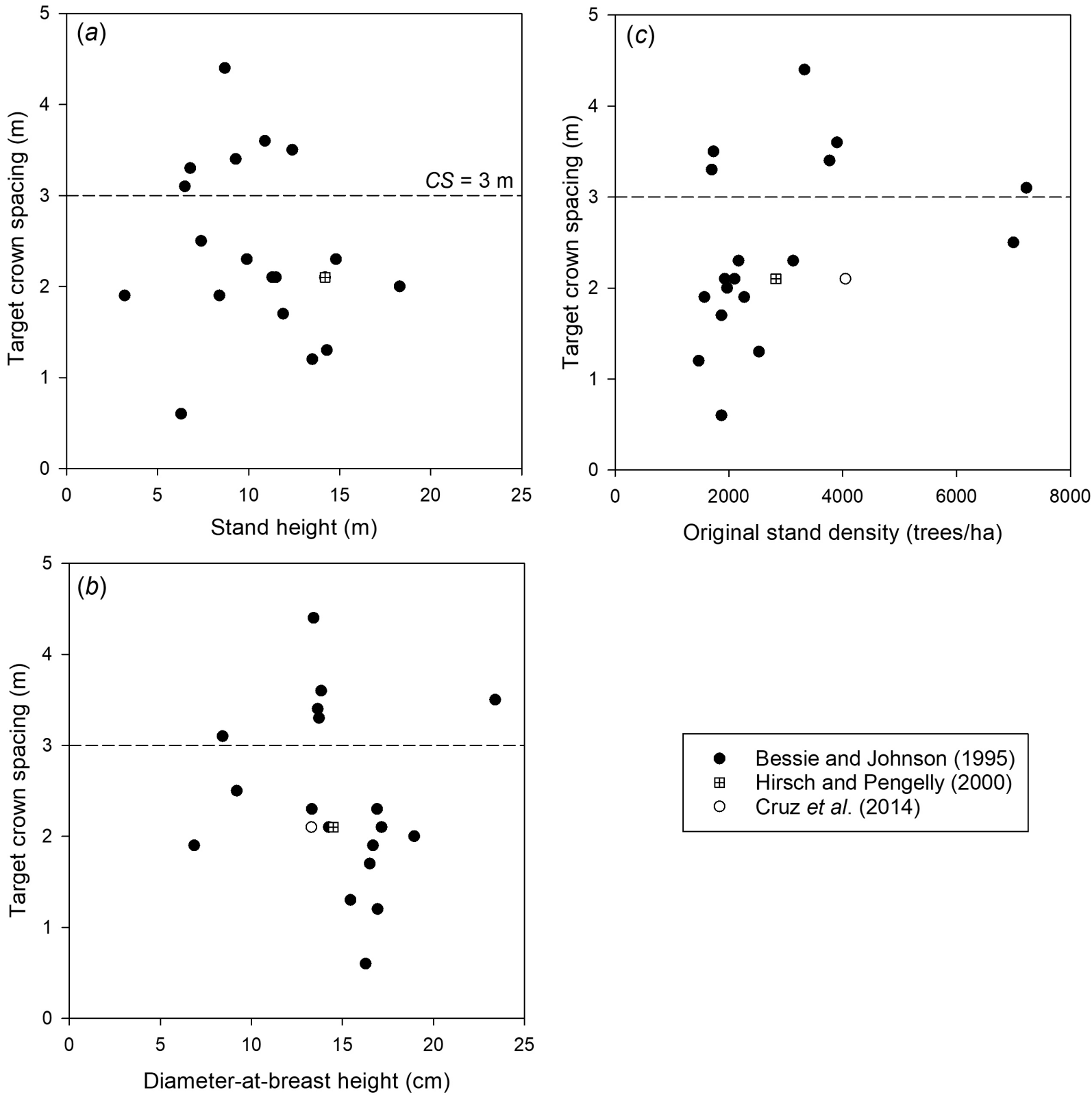

Fig. 3 Resultant crown spacing (CS), assuming a targeted canopy bulk density of $0.05 \mathrm{~kg} / \mathrm{m}^{3}$ following thinning, as a function of (a) average tree height, (b) average diameter-at-breast height and (c) initial stand density for the 20 lodgepole pine stands located in Alberta.

important factor influencing the onset of crowning and sustained crown fire spread. It might be expected that thinning of a fully or overstocked stand would lead to an increase in the average $\mathrm{CBH}$ as a result of removing many of the younger trees that effectively serve as ladder fuels. Nonetheless, for older and not fully stocked stands, there might be a need to consider how thinning is affecting the $\mathrm{CBH}$ and the potential for crown fire initiation.

The effect of a silvicultural treatment on fire behaviour potential associated with a stand has further implications than just the direct changes on fuel structure. As an example, maintaining a denser stand (i.e., less than 3-m between crowns) does have the advantage of creating favourable microclimatic conditions more conducive to diminishing surface and crown fire potential compared to a more open stand created by thinning. This would include decreasing instand winds (Whitehead et al. 2008), especially near the forest edge, and increasing the moisture content of fine, dead surface fuels (Schroeder et al. 2006; Whitehead et al. 2008). A denser stand would in the long run also favour wind firmness (Mitchell 1998), as lodgepole pine forests subjected to thinning can be susceptible to windthrow given its shallow rooted nature. It is uncertain how understorey vegetation would respond to thinning and, in turn, affect fire potential. The opening up of a stand could, for example, lead to an increase in the growth of understorey white spruce (Picea glauca 
(Moench) Voss), if present, and minor vegetation (i.e., herbaceous plants and shrubs) (Kiil 1968).

However, the direct costs of fuel management and the implications for community safety and fire management at large warrant fuel treatment planning be based on the best science available, rather than continuing to rely on an overly simplistic guideline that lacks a firm scientific basis. A growing number of software tools (e.g., Lutes 2020) enable fire and forest managers to estimate the immediate impact of stand manipulation on the fuel complex, and how a forest's inherent flammability evolves through time (Johnson and Peterson 2005). The Canadian Conifer Pyrometrics decision support aid (Perrakis et al. 2020), for example, which combines models of fuel moisture and surface and crown fire behaviour will permit managers to assess the effect(s) of proposed fuel treatments (that rely on silviculture and other vegetation management techniques) on crowning potential. The use of such tools will allow the development of targeted and more efficient fuel treatment prescriptions based on actual stand and canopy fuel characteristics rather than a generalized 3-m between crown spacing guideline.

The rather simplistic cases presented in this paper raise some important issues that need to be explored in greater detail both from the standpoint of field experimentation and various modelling perspectives (e.g., examine additional tree and stand structure combinations and consider the effects of stand development through time). This would rely upon using the latest knowledge of the interactions of surface fuel loads, fuel moisture and wind speed levels, ladder fuels, and canopy fuel characteristics on crown fire initiation, spread and cessation.

Other crown fire-prone coniferous forest cover types found across Canada should be considered for evaluation using the same general methodology as used in this paper. Black spruce (P. mariana (Mill.) BSP) and jack pine (Pinus banksiana Lamb.) forests, for example, are increasingly being subjected to fuel treatments (Schroeder 2010; Hvenegaard et al. 2016).

\section{List of abbreviations and symbols, quantities, and units used in equations and text}

$C B D$, canopy bulk density $\left(\mathrm{kg} / \mathrm{m}^{3}\right)$

$C B D_{t}$, canopy bulk density following thinning $\left(\mathrm{kg} / \mathrm{m}^{3}\right)$

$\mathrm{CBH}$, canopy base height $(\mathrm{m})$

$C D$, crown depth $(\mathrm{m})$

$C F L$, canopy fuel load $\left(\mathrm{kg} / \mathrm{m}^{2}\right)$

$C F L_{t}$, canopy fuel load following thinning $\left(\mathrm{kg} / \mathrm{m}^{2}\right)$

$C S$, crown spacing $(\mathrm{m})$

$C W$, crown width (m)

$D B H$, diameter-at-breast height $(\mathrm{cm})$

$F M C$, foliar moisture content (\% oven-dry weight basis)

$H$, low heat of combustion reduced for fuel moisture content $(\mathrm{kJ} / \mathrm{kg})$

$I_{B}$, fireline intensity $(\mathrm{kW} / \mathrm{m})$

$I_{o}$, critical surface intensity needed for initial crown combustion $(\mathrm{kW} / \mathrm{m})$

$I C O$, inter-crown overlap $(\mathrm{m})$

$R$, surface or crown rate of fire spread $(\mathrm{m} / \mathrm{min})$

$R_{o}$, critical minimum spread rate for active crown $(\mathrm{m} / \mathrm{min})$

$S$, average spacing between tree stems $(\mathrm{m})$

$S_{t}$, desired tree spacing following thinning $(\mathrm{m})$

$S D$, stand density (stems/ha)
$S D_{t}$, stand density following thinning (stems/ha)

$\mathrm{SH}$, stand height (m)

$w$, fuel consumed in the flaming front $\left(\mathrm{kg} / \mathrm{m}^{2}\right)$

\section{Acknowledgements}

The authors appreciate the comments received from Rick Arthur, Al Beaver, Paulo Fernandes, Dave Finn, Brad Hawkes, Dana Hicks, Steve Hvenegaard, Kris Johnson, Sonja Leverkus, Ralph Nelson, Phil Omi, Wesley Page, Dan Perrakis, Dave Schroeder, Steve Taylor and three anonymous reviewers on earlier versions of this paper.

\section{References}

Agee, J.K. 1996. The influence of forest structure on fire behavior. In: J. Sherlock (ed.). Proceedings of the $17^{\text {th }}$ Annual Forest Vegetation Management Conference (Jan. 16-18, 1996, Redding, CA). pp. 52-57. For. Vegetation Manage. Conf., Redding, CA.

Agee, J.K. and C.N. Skinner. 2005. Basic principles of forest fuel reduction treatments. For. Ecol. Manage. 211: 83-96.

Alberta Government. 2013. FireSmart guidebook for community protection - a guidebook for wildland/urban interface communities. Alta. Environ. Sustainable Resour. Develop., Prov. For. Fire Cent., Edmonton, AB. 92 pp.

Alexander, M.E. 1982. Calculating and interpreting forest fire intensities. Can. J. Bot. 60: 349-357.

Alexander, M.E. 2000. Fire behaviour as a factor in forest and rural fire suppression. For. Res., Rotorua in assoc. N.Z. Fire Serv. Comm. and Natl. Rural Fire Authority, Wellington, NZ. For. Res. Bull. No. 197, For. Rural Fire Sci. Tech. Ser. Rep. No. 5. 28 pp.

Alexander, M.E. and M.G. Cruz. 2006. Evaluating a model for predicting active crown fire rate of spread using wildfire observations. Can. J. For. Res. 36: 3015-3028.

Alexander, M.E. and M.G. Cruz. 2016. Chapter 9: crown fire dynamics in conifer forests. In: Synthesis of Knowledge of Extreme Fire Behavior: Volume 2 for Fire Behavior Specialists, Researchers and Meteorologists. pp. 163-258. USDA For. Serv., Pac. Northw. Res. Stn., Portland, OR. Gen. Tech. Rep. PNW-GTR-891.

Amiro, B.D., W.J. de Groot, P. Bothwell, A.L. Westhaver and P.L. Achuff. 2004. Impacts of fire and elk herbivory in the Montane Ecoregion of Jasper National Park, Alberta, Canada. In: R.T. Engstrom, K.E.M. Galley and W.J. de Groot (eds.). Proceedings of the 22 $2^{\text {nd }}$ Tall Timbers Fire Ecology Conference: Fire in Temperate, Boreal, and Montane Ecosystems (Oct. 15-18, 2001, Kananaskis Village, AB). pp. 258-264. Tall Timbers Res. Stn., Tallahassee, FL.

Arbor Wildland Management Services. 1991. Wildland-urban interface forest fire potential and fuel reduction plan for Banff townsite and surrounding area. Final report to Banff Park Warden Service, Banff National Park. Arbor Wildland Manage. Serv., Edmonton, AB. 169 pp. + appendices.

Bessie, W.C. and E.A. Johnson. 1995. The relative importance of fuels and weather on fire behavior in subalpine forests. Ecology 76: 747-762.

BonFire Steering Committee. 2016. Bonner County wildfire protection plan. Bonner County, Sandpoint, ID. 53 pp.

Bonnor, G.M. 1964. The influence of stand density on the correlation of stem diameter with crown width and height for lodgepole pine. For. Chron. 40: 347-349.

Byram, G.M. 1959. Combustion of forest fuels. In: K.P. Davis (ed.). Forest Fire: Control and Use. pp. 61-89, 554-555. McGraw Hill, New York, NY.

Colorado State Forest Service. 2012. Protecting your home from wildfire: creating wildfire-defensible zones. CSFS, Fort Collins, CO. Quick Guide Ser. FIRE 2012-1. 12 pp.

Countryman, C.M. 1974. Can Southern California wildland conflagrations be stopped? USDA For. Serv., Pac. Southw. For. Range Exp. Stn., Berkeley, CA. Gen. Tech. Rep. PSW-7. 11 pp. 
Cruz, M.G. and M.E. Alexander. 2010. Assessing crown fire potential in coniferous forests of western North America: a critique of current approaches and recent simulation studies. Int. J. Wildland Fire 19: 377-398.

Cruz, M.G. and M.E. Alexander. 2012. Evaluating regression model estimates of canopy fuel stratum characteristics in four crown fire prone fuel types in western North America. Int. J. Wildland Fire 21: 168-179.

Cruz, M.G., M.E. Alexander and J.E. Dam. 2014. Using modeled surface and crown fire behavior characteristics to evaluate fuel treatment effectiveness: A caution. For. Sci. 60: 1000-1004.

Dam, J.E. 1999. Effects of thinning on fire behaviour: A case study in lodgepole pine in Canada. Wageningen Univ., Wageningen, Netherlands. M.Sc. Thesis. 65 pp.

Davis, K.P. 1966. Forest management. $2^{\text {nd }}$ ed. McGraw-Hill, New York, NY. 519 pp.

Dennis, F.C. 1983. Fuelbreak guidelines for forested subdivisions. Colo. State Univ., Colo. State For. Serv., Fort Collins, CO. 16 pp.

Dennis, F.C. 2005. Fuelbreak guidelines for forested subdivisions \& communities. Colo. State Univ., Colo. State For. Serv., Fort Collins, CO. 8 pp.

Fischer, W. and D. Simmerman. 1990. Quick calculations of wildland homes fire risk. Wildfire News and Notes 4(1): 12.

Fish, H., V.J. Lieffers, U. Silins and R.J. Hall. 2006. Crown shyness in lodgepole pine stands of varying stand height, density, and site index in the upper foothills of Alberta. Can. J. For. Res. 36: 2104-2111. Fingland, R. 1987. Seasonal foliar moisture trends in Banff National Park. Univ. British Columbia, Vancouver, BC. B.Sc.F. Thesis. 70 pp. Forestry Canada Fire Danger Group. 1992. Development and structure of the Canadian Forest Fire Behavior Prediction System. For. Can., Sci. Sustainable Develop. Directorate, Ottawa, ON. Inf. Rep. ST-X-3. 63 pp.

Fuglem, P.L. and P.J. Murphy. 1980. Foliar moisture content and crown fire in Alberta. Alta. Energy Nat. Resour., Alta. For. Serv., Edmonton, AB. ENR Rep. No. 158. 47 pp.

Graham, R.T., A.E. Harvey, T.B. Jain and J.R. Tonn. 1999. The effects of thinning and similar stand treatments on fire behavior in Western forests. USDA For. Serv., Pac. Northw. Res. Stn., Portland, OR. Gen. Tech. Rep. PNW-GTR-463. 27 pp.

Hvenegaard, S., D. Schroeder and D. Thompson. 2016. Fire behaviour in black spruce forest fuels following mulch fuel treatments: A case study at Red Earth Creek, Alberta. FPinnovations, Pointe-Claire, QC. Tech. Rep. No. 42.29 pp.

Hirsch, K. and I. Pengelly. 2000. Fuel reduction in lodgepole pine stands in Banff National Park. In L.F. Neuenschwander, K.C. Ryan, G.E. Goldberg and J.D. Greer (eds.). Proceedings of Joint Fire Science Conference and Workshop (June 15-17, 1999, Boise, ID), Volume II. pp. 251-257. Univ. Idaho, Moscow, ID and Int. Assoc. Wildland Fire, Fairfield, WA.

Hunter, M.E., W.D. Shepperd, J.E. Lentile, J.E Lundquist, M.G. Andreu, J.L. Butler and F.W. Smith, 2007. A comprehensive guide to fuels treatment practices for ponderosa pine in the Black Hills, Colorado Front Range, and Southwest. USDA For. Serv., Rocky Mt. Res. Stn., Fort Collins, CO. Gen. Tech. Rep. RMRS-GTR-198. 93 pp. Institute of Catastrophic Loss Reduction. 2019. Protect your home from wildfire. ICLR, Toronto, ON. 24 pp.

Jones, C., C. Dennett and D. Garcia. 2016. Living with wildfire: homeowners' Firewise guide for Arizona (Revised). Multi-agency collaborative pamphlet. Univ. Ariz., Coll. Agric. Life Sci., Tucson, AZ. Publ. \#AZ1416-2016. 24 pp.

Johnson, M.C. and D.L. Peterson. 2005. Forest fuel treatments in western North America: merging silviculture and fire management. For. Chron. 81: 365-368.

Kiil, A.D. 1968. Weight of the fuel complex in 70-year-old lodgepole pine stands of different densities. Can. Dep. For. Rural Develop. For. Branch, Ottawa, ON. Dep. Publ. 1228. 9 pp.
Lawson, B.D. 1973. Fire behavior in lodgepole pine stands. Dep. Environ., Can. For. Serv., Pac. For. Res. Cent., Victoria, BC. Inf. Rep. BC-X-76. 26 pp.

Lutes, D.C. 2020. FuelCalc 1.7 user guide. USDA For. Serv., Fire Aviation Manag., Washington, DC and Rocky Mt. Res. Stn., Fire Model. Instit., Missoula, MT. 85 pp.

McArthur, A.G. 1965. Fire behaviour characteristics of the Longford Fire. Commonw. Aust., For. Timber Bureau, For. Res. Instit., Canberra, ACT. Leafl. 91.19 pp.

Mitchell, S.J. 1998. A diagnostic framework for windthrow risk estimation. For. Chron. 74: 100-105.

National Fire Protection Association. 1991. NFPA 299 standard for protection of life and property from wildfire. $1991 \mathrm{ed}$. NFPA, Quincy, MA. 19 pp.

Partners in Protection. 2003. FireSmart: protecting your community from wildfire. $2^{\text {nd }}$ ed. PIP, Edmonton, AB. 165 pp.

Pengelly, I. 1993. Forest fire protection for the town of Banff and village of Lake Louise in Banff National Park. In: K.G. Hirsch (comp.). Proceedings of Minimizing the Risk of Wildfire: A Symposium to Address the Wildfire Problems in the Wildland/Urban Interface (Sep. 27-30, 1992, Jasper, AB). pp. 97-101. Partners in Protection, $\mathrm{AB}$.

Perrakis, D.D.B., M.G. Cruz, M.E. Alexander, S.W. Taylor and J.L. Beverly. 2020. Linking dynamic empirical fire spread models: Introducing Canadian Conifer Pyrometrics. In: Proceedings of $6^{\text {th }}$ Fire Behavior and Fuels Conference (Apr. 29-May 3, 2019, Albuquerque, NM, Sydney, NSW, Marseille, FR). Int. Assoc. Wildland Fire, Missoula, MT. 66-72.

Rudnicki, M., U. Silins and V.J. Lieffers. 2004. Crown cover is correlated with relative density, tree slenderness, and tree height in lodgepole pine. For. Sci. 50: 356-363.

Schmidt, W.C. and R.H. Wakimoto. 1988. Cultural practices than can reduce fire hazards to homes in the Interior West. In: W.C. Fisher and S.F. Arno (comps.). Proceedings of Symposium and Workshop on Protecting People and Homes from Wildfire in the Interior West. pp. 131-141. USDA For. Serv., Intermt. Res. Stn., Ogden, UT. Gen. Tech. Rep. INT-251.

Schroeder, D. 2010. Fire behaviour in thinned jack pine: two case studies of FireSmart treatments in Canada's Northwest Territories. FPInnovations, Pointe-Claire, QC and Vancouver, BC. Advantage 12(7). $12 \mathrm{pp}$.

Schroeder, D., G. Russo, J. Beck, B. Hawkes and G. Dalrymple. 2006. Modelling ignition probability of thinned lodgepole pine stands. For. Eng. Res. Instit. Can., Pointe-Claire, QC and Vancouver, BC. Advantage 7(12). 8 pp.

Stocks, B.J. 1989. Fire behavior in mature jack pine. Can. J. For. Res. 19: 783-790.

Stocks, B.J., M.E. Alexander, B.M. Wotton, C.N. Stefner, M.D. Flannigan, S.W. Taylor, N. Lavoie, J.A. Mason, G.R. Hartley, M.E. Maffey, G.N. Dalrymple, T.W. Blake, M.G. Cruz and R.A. Lanoville. 2004. Crown fire behaviour in a northern jack pineblack spruce forest. Can. J. For. Res. 34: 1548-1560.

Van Wagner, C.E. 1964. History of a small crown fire. For. Chron. 40: 202-205, 208-209.

Van Wagner, C.E. 1977. Conditions for the start and spread of crown fire. Can. J. For. Res. 7: 23-34.

Westhaver, A.L. 2006. FireSmart and ForestWise: managing wildlife and wildfire risk in the wildland/urban interface. Univ. Calgary, Calgary, AB. M.Sc. Thesis. 222 pp.

White, C.A. 1985. Fire and biomass in Banff National Park closed forests. Colo. State. Univ., Fort Collins, CO. M.Sc. Thesis. 205 pp.

Whitehead R.J., G.L. Russo, B.C. Hawkes, S.W. Taylor, B.N. Brown, O.B. Armitage, H.J. Barclay and R.A. Benton. 2008. Effect of commercial thinning on within-stand microclimate and fine fuel moisture conditions in a mature lodgepole pine stand in southeastern British Columbia. Nat. Resour. Can., Can. For. Serv., Can. Wood Fibre Cent., Victoria, BC. Inf. Rep. FI-X-004. 16 pp. 